This is an electronic reprint of the original article. This reprint may differ from the original in pagination and typographic detail.

Please cite the original version: P. Lehto, J. Porokuokka (2018) DESIGNING AND IMPLEMENTING A NEW JOINT COURSE BASED ON RESEARCH, SERVICE ROBOTS AND CONCEPT DEVELOPMENT, INTED2018 Proceedings, pp. 8030-8036.

doi: 10.21125/inted.2018.1937 


\title{
DESIGNING AND IMPLEMENTING A NEW JOINT COURSE BASED ON RESEARCH, SERVICE ROBOTS AND CONCEPT DEVELOPMENT
}

\author{
P. Lehto, J. Porokuokka \\ Laurea University of Applied Sciences (FINLAND)
}

\begin{abstract}
Digital revolution and automation play an important role in finding new solutions to actual social issues such as aging the population and developing welfare services and the productivity of welfare services. The evolution of artificial intelligence, robotics and cognitive robots has been considered as one way to develop new services, improve the quality of their services, and increase productivity [1]. Successful interaction between humans and robots is one of the most important challenges of future technology.

As in any other field of industry, digitalization is changing education and especially health care. This change is ongoing and profound as it affects every level in society. The magnitude of this change is so huge that some label it as the health care revolution. [2]. Changes in work require updating the skills. Use of technology, automation and robotics in different fields require new kind of expertise and training. New requirements in work also set demands for education to use technology [3].

Innovative use of technology, especially using robotics in real life settings during the education, is still weak. New requirements also create demands on curriculum development

The purpose of this article is to find out how research project can be the context and new way to learn competences regarding service robots and concept development. The focus is on how to plan and implement a new joint course in master degree level. The content and the process present how student learn in real life situation in a context of a research project. This study is a starting point for planning and conducting Living Lab research towards achieving new competences during master degree studies at Laurea University of Applied Sciences.
\end{abstract}

Keywords: Design, health and social care, living lab, master program, robots.

\section{INTRODUCTION}

\subsection{Background}

Globalization, the cyber revolution and computer science, economic competition and the broad spread of knowledge are main milestones in our decade. [4].

Information and communication technologies enable processing of information and enable transforming information quickly to the practice and in everyday life actions. This is widely evident in education and working life in general. There is a huge challenge to utilize information and communication technologies in education and in practice health care and social care fields.

According to work done in the OECD Health Policy Studies 2010 a new way to apply ICT in health area is dedicated to improve health quality, reducing costs and supporting new models of care [5]. Technological progress offers great potential in the acquisition of health information, care and services. It forges technologies into increasingly powerful tools with expanding possibilities for the development of health education and prevention programs. [4].

Digitalization and automatization are spreading rapidly and affecting all levels of the society based on EU2014. This is an important also in education and curriculum development concerns in many fields.[6].

\subsection{Robotics}

Studies show that robots can be divided into medical robots, institutional robots, personal assistive robots and care robots. Robots are categorized based on different characteristics: such as care 
robots, service robots and social robots [7]. Robots are applied e.g. in elderly care so that robots move, monitor or remind a person to take a medication. Remote online connection is possible via robots. Robots are also able to provide entertainment in forms of games, music and interaction with the person. [8].

Nowadays robots are increasingly able to perform not only manual and routine cognitive tasks but also non-routine and cognitive tasks. In service robotics, the circumstances differ from those of industrial robotics because the environment can only very rarely be completely designed with regard to the use of the robots. [9]. The use of service robots differ a lot from industrial when the robots are intended to interact with humans in close contact. The challenge is that the robot system must react flexibly in different environments in which they render services to humans.

Leminen et al (2017) label four archetypes of service innovations stimulated by robots in health and welfare living labs. The archetypes of robotic service innovations are socializing, aiding, entertaining, and personal assisting.[10].

Based on earlier studies there are positive attitudes towards using robots, e.g. towards robots, which are able to carry out heavy, dangerous and difficult tasks.[11]. In addition, Eurobarometer survey 2012 shows that most of informants accept robots taking care of everyday hard work but do not see many benefits of robots in health care or in their own personal life. Only few (18\%) approve use of robots in healthcare context.[12].

\subsection{New Competences}

The need to continue developing education and training for the health and social care workforce to meet emerging health and social care challenges is apparent. This is highlighted by the global challenge of meeting the needs of for example elderly people with multiple and complex conditions.

Based on literature search Uerz et al (2018) found and identified following domains of competences:

1 Technology competences meaning the ability to use technology in general (can be related to teaching and learning)

2 Competences for pedagogical and educational use of technology

3 Beliefs about teaching and learning

4 Competences for innovation and professional learning [13].

Professional development and changing practices stipulate new requirements and make demands for education to use technology [3]. Innovative use of technology, especially using robotics in real life settings during the education is still weak. New requirements also set demands for curriculum development.

Educators not only deliver the content of their courses, but also teach and model use of technology, pedagogical beliefs and instructional strategies [14]. The ultimate purpose when using technology is to help and improve quality of human life. Ortega-Navas (2016) underlines that the contributions of new technologies have made change to some of the paradigms used in health sector for example in health promotion. Technologies have also changed the mission of education in this area by helping to improve quality of life and facilitate shared information and communication among health practitioners and between health practitioners and their patients. [4]. Automatization and robotics in working life and e.g. in healthcare and social welfare field demand special competences and new contents in curriculum.

\subsection{Case ROSE project}

The study is a part of a larger research project called Robots and Future of Welfare Services (ROSE), funded by Strategic Research Council, Academy of Finland. The project adopts a multidisciplinary and holistic approach to study how advances in robot and perception technologies allow product and service innovation and renewal of welfare services, when such services are developed jointly with users and other stakeholders. In addition the uptake of new services requires study of ethical issues and stakeholder participation. By joining efforts across disciplines, this project aims to go beyond the controversy between technological determinism and social constructivism to help re-define future welfare services. [15]. 


\section{METHODOLOGY}

\subsection{Living Lab Methodology and implementation}

Living lab is defined as a network that integrates user-centered research and open innovation [16]. For example, Leminen and Westerlund define Living labs as physical regions or virtual environments where public-private-people partnerships can happen. In Living labs companies, entrepreneurs, academic organizations and users are able to create, test and validate new products and services especially in real life situations [17]. Based on the literature, Living lab can present either as a method or as a methodological approach [16]. The goal is to study a phenomena in real life contexts and the research process involves actions in real life [17]. The basic principles of Living Lab are congruent with the action research [18] because both are based on the critical knowledge interest referring Habermas' knowledge interests [19]. Living lab research aims towards changing something. The research interventions are related the concept of change and the aim of Living lab research is to solve problems and to find out new solutions. Living lab is an environment that offers future directions for product development based on users' experiences. Product development can be related to new products, services and applications through a cocreation process. [20],[21 ].

In this article Living lab as a methodological approach and as a real life environment offers the context in which research has been and will be implemented. The phenomena of service robots and development of business concepts has been studied through research orientation and process in real life setting. This context also serves as the platform for the course and as a learning environment for the students. Cocreation and codesign together with different actors including students, researchers, professionals and elderly people provides new possibilities to achieve new competences for developing robotics to support user's health and wellbeing as well as working life.

For students Living lab methodology and action research approach are the basis of participating in ROSE project. Living lab is stimulating interaction between students and other actors. In addition, used creative methods have supported participation and involvement during the implementations of the course.

Small community, with 34000 inhabitants, in southern part of Finland serves as the project's living lab environment. In ROSE project elderly people and home care professionals serve the role of users for developing robotics in elderly care. According to von Hippel lead users are important actors and display two main characteristics: lead users face needs long before the others in the market and lead users expect to have a significant benefit when they participate and obtain new solutions to address these needs [22].

In the ROSE project during the past two years both elderly people $(\mathrm{N}=32)$ living at a service house or at private home and home care professionals $(\mathrm{N}=40)$ have participated in the main study. Mixed methods, such as focus group interviews with SWOT analysis, survey, videos and demos, have been used in user data collection. Based on action research, as the methodological approach and the living lab methodology have been the basis for the research, especially when developing and piloting new activities, methods or interventions, such as contents and services with Pepper robot in real life.

\subsection{The purpose and research tasks}

This study examines how the joint course of "Research, social robots and concept development" enables master students to achieve new competences in social robots applied to elderly care. The main aim is to respond to the challenges in health care and social welfare field while developing and piloting robotic services with students in real life context.

The research task is to find out how to design and implement the joint course based on research and development in real life setting to see the types of and findings to be found and to explore how robotics can be applied in elderly care.

\section{RESULTS}

\subsection{Students as actors in the study}

Laurea University of Applied Sciences offers twelve Master's degree programs (90 credits). The degree includes 30 credits of program-specific core competences, 30 credits of elective studies and a thesis of 30 credits. The core competences are supplemented by Laurea's joint offer of 
complementary studies, in which the student can select 30 credits of management and development studies. It is also possible to select elective studies from the core studies of other programme. Research development and innovation, working life orientation and extensive network of stakeholders are deeply linked in studies. [23].

The participating students were studying in three master's degree programs: Service Innovation and Design, Security Management and Leadership and Management in Health care and Social Welfare. Students in this course were representing different working fields such as management and leadership in health and social welfare, security and emergency service, tourism and insurance industry. Students had the minimum of three years working experience.

Social learning is based on a cyclic process and iterative relationship between user representation, design and appropriation [24]. Social learning is similar as the basis of action research approach. Both require engaged cooperation during the process with the actors in real life contexts. Students were able to cooperate authentically in multiprofessional team and learn from each other. Through this multiprofessional teamwork students could also grasp the meaning of Living lab approach as in Living lab studies research groups are often multidisciplinary.

\subsection{Design and implementation of the joint course}

The course Research, Service robots and Concept Development (five credits) is part of elective studies in master degree program. The goals and the structure of the course were in figured in the context of ROSE project. The goals of the study unit in the master program curriculum are:

Student is able

- to understand service and social robots

- to learn fundamentals of Living lab and service design methods

- to analyze and visualize customer needs in order to create digital service concepts

- to document the results. The topic of the course was to design digital services for service and social robots.

The purpose of the studies was to support students' active participation and involvement. During the first session teachers as researchers presented ongoing ROSE -project and the Living lab methodology. In the same time social robot, Pepper was demonstrated and students were able to achieve their first contact with Pepper robot. (Fig.1)

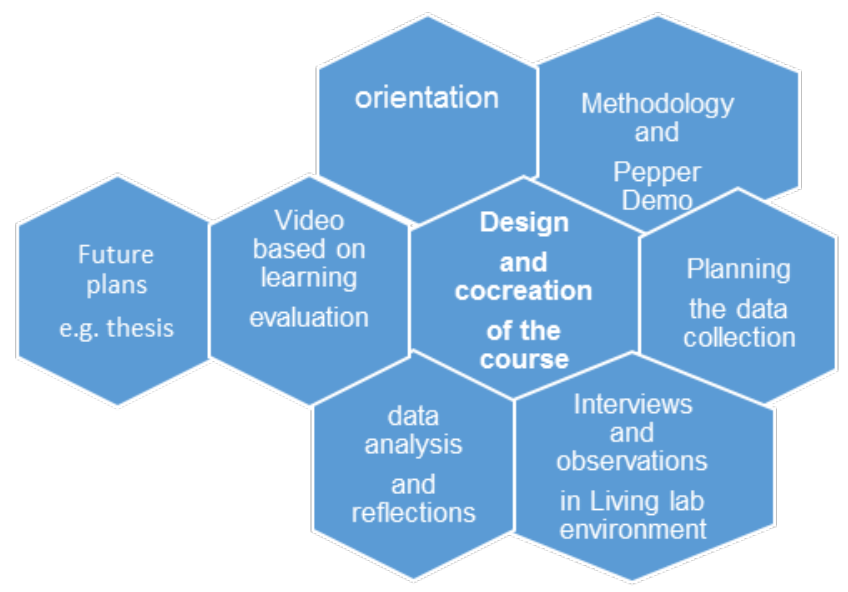

Figure 1 The structure of the course.

There were a lot of discussions and ideas about how robots, Pepper in particular, can be developed and applied in working life in different fields with various clients and in different situations. Students planned the data collection including interviews and observations of the elderly people in real life in Living lab environment. The ethical permission for the study was given by the stakeholders from the community. Participants wrote informed consent. The purpose of the data collection was to grasp the meaning of activities of daily living and the rhythm of daily life. 
The data collection methods were interviews and active observation. [26]. Students and researchers interviewed during four elderly people. All participants were customers of homecare services. One participant lived in her private home and three in small group service house. Participative observation was used as a supportive method to collect the data for developing services and for Pepper robot. The data was recorded and observations were written on memos. The data was later analyzed using inductive content analysis [27]. The students and researchers together analyzed and summarized the data.

\subsection{Findings of the data}

In this study, master students were actively participating in research project with users and professionals for achieving and co creating new competences of service robots and concept development. During the first stage of the project the current state of home care was analyzed and home care workers' needs and expectations of how to use robots in elderly care were mapped and analyzed. Demo sessions with five different robots were organized and both elderly people and caregivers participated in the workshop. Based on the findings of this data, we chose Pepper to be the robot to conduct and continue the research. Two pilots with Pepper robot implemented during spring 2017, the first one being a Bingo session with Pepper, and the second one a session of physical exercises with Pepper guiding the elderly.

Based on the collected the data during the joint course the suggestions for future service development using social robot Pepper were categorized and are presented in table 1.

Table 1. Ideas for design.

\begin{tabular}{|l|l|l|}
\hline \multicolumn{1}{|c|}{ challenge/ problem } & \multicolumn{1}{|c|}{ idea } & \multicolumn{1}{c|}{ plan for Pepper } \\
\hline $\begin{array}{l}\text { loneliness } \\
\text { isolation }\end{array}$ & $\begin{array}{l}\text { activation } \\
\text { games } \\
\text { reading } \\
\text { music }\end{array}$ & $\begin{array}{l}\text { design reading and discussions newspaper } \\
\text { with Pepper }\end{array}$ \\
\hline memory problems & $\begin{array}{l}\text { remembering } \\
\text { personal life history }\end{array}$ & $\begin{array}{l}\text { designing individual personalized memory } \\
\text { box (life history, photos, places etc.) }\end{array}$ \\
\hline lack of relationships & $\begin{array}{l}\text { online discussions (friends, } \\
\text { significant others) }\end{array}$ & $\begin{array}{l}\text { interactive contact } \\
\text { by online video }\end{array}$ \\
\hline $\begin{array}{l}\text { lack of communication and } \\
\text { using computers }\end{array}$ & learning and support via Pepper & Pepper guides how to use e.g. TV \\
\hline daily routines & reminder & Pepper reminds the day, time, dining etc. \\
\hline
\end{tabular}

The basis of Living Lab approach is on collaboration with users. Cocreation with users enhance real and user-driven solutions. However, as elderly people rarely have experience in service robots, it would be beneficial to create service concept as demos with and for them. During the interviews, elderly people constantly bring up their desire to keep themselves up to date on what is happening in the world and their community. However, they are limited to more traditional news sources, e.g. television and radio. Newspapers are an option, but for many, reading has become a challenge due to deteriorating eyesight. Using Pepper as an interface, the elderly could have access to various online news sources. Pepper could also actively recommend them articles based on their interests and likings and read them aloud to the seniors, showing images from the news on the robot's display.

Becoming passive, both physically and socially, causes major issues with aging. Social robots could be used to take initiative in activating seniors in different types of activities, such as physical exercise, playing memory enhancing exercise games, and contacting the seniors' relatives. However, there's a fine balance in how often and what types of activities the robot should recommend, and this is also where artificial intelligence could be deployed to create a personal profile that adjusts according to the user's preferences regarding the timing and frequency of taking initiative, as well as the type of activity that the robot is recommending. Depending on the activity level of the senior, in some cases the seniors just lay down on their beds waiting for home care to visit them. It might be interesting to explore whether a robot could increase their level of activity. Quite often elderly people themselves do not recognize their own memory problems while caregivers often do. Deteriorating memory causes 
many problems, as the elderly people don't necessarily remember to take their medication or take initiative to complete their daily routunes. Reminders via a robot might be also be one content and service for elderly people still coping independently at home. From the research process during the course "research, service robots and concept development" findings from multiple sources and rich data was emerged and will guide and show the directions where to go and develop further pilots in Living lab.

\section{CONCLUSIONS}

Research projects enable learning in various ways. Rose project and Living lab methodology offered deep learning platform for master students. Active participation with users in real life situations anchored learning towards research-based competences.

Based on the findings and cocreation process during the joint course new perspectives, contents and services for social robots in elderly care were found. The upcoming challenge is to choose and design for piloting more user-driven services and contents with Pepper. The aim is to continue and plan two or four pilots during the next year.

\section{ACKNOWLEDGEMENTS}

We express our gratitude to master students participating in joint course organized in ROSE project. In addition, we thank all research partners and especially participating elderly people in Living lab.

\section{REFERENCES}

[1] $\quad H$ Erikson and M Salzmann-Erikson, Future Challenges of Robotics and Artificial Intelligence in Nursing: What Can We Learn from Monsters in Popular Culture? The Permanente Journal Jul (20 (3), 215-243, 2016.

[2] J Lahtiranta, Mediator - enabler for successful digital health care. Finjehew. Vol9.NO 4, 284298, 2017. file:///C:/Users/pauleht/AppData/Local/Microsoft/Windows/INetCache/IE/ XWWNWGUH/60923-85-82138-1-10-20171129\%20(1).pdf

[3] J Tondeur, J Van Braak, S Guoyuan, J Voogt, P Fisser and A.S Ottenbreit-Leftwich, Preparing student teachers to integrate ICT in classroom practice: A synthesis of qualitative evidence. Computers \& Education, 59(1), 134e144, 2012. https://doi.org/10.1016/j.compedu.2011.10.009

[4] M Ortega-Navas, The use of new technologies as a tool for the promotion of heath. 7 th International Conference on Intercultural Education "Education, Health and ICT for aTranscultural World", EDUHEM 2016, $15-17$ June 2016, Almeria, Spain, 2017. https://ac.elscdn.com/S187704281730006X/1-s2.0-S187704281730006X-main.pdf?_tid=e2b8ba5c-f86111e7-885800000aacb35d\&acdnat=1515848676_6043ff7afdaf61d13c22ae8c2ad14d6f

[5] OECD 2010 OECD Health policy studies - improving health efficiency, 2010. http://www.oecd.org/els/health-systems/45503987.pdf

[6] European Commission.A Digital Agenda for Europe - Rebooting Europe's Economy, 2014. https://europa.eu/europeanunion/topics/digital-economy-society_en.

[7] M Kangasniemi, A-M Pietilä and A Häggman-Laitila, Automatiikka ja robotiikka hoitotyöntekijöiden työn muutoksessa. Tutkiva Hoitotyö 14(2),40-45, 2016.

[8] M Mataric', A Okamura and H.A Christensen, Research Roadmap for Medical and Healthcare Robotics. In: A Roadmap for US Robotics. From Internet to Robotics; http://www.usrobotics.us/reports/CCC\%20Report.pdf; retrieved 28 July, 2015

[9] M Decker, The next generation of robots for the next generation of humans? Robotics and Autonomus System.Vol 88,154-156, 2017. https://ac.els-cdn.com/S0921889016307114/1-s2.0S0921889016307114-main.pdf? tid=1d383804-f85f-11e7-872400000aab0f6b\&acdnat=1515847494_0edfe5ea288b4e58c43be2bd3d7f3fe7

[10] S Leminen, M Westerlund and M Rajahonka, Innovating with service robots in living labs. ISPIM Innovation Symposium; Manchester: 1-15. Manchester: The International Society for Professional Innovation Management (ISPIM), 2017. 
[11] R Kachoie, S Sedighadeli, R Khosla and MT Chu MT, Socially assistive robots in elderly care: a mixed-methos systematic literature review. International Journal of Human-Computer Interaction. 30, 5, 369-393, 2014. http://www.tandfonline.com/doi/full/10.1080/ 10447318.2013.873278?scroll=top\&needAccess=true

[12] Special Eubarometer 382, 2012. http://ec.europa.eu/public_opinion/archives/ebs/ebs_382_en.pdf

[13] D Uerz, M Volman and M Kral, Teacher educators' competences in fostering student teachers' proficiency in teaching and learning with technology: An overview of relevant research literature. Teaching and Teacher Education Vol 70, 12-23, 2018. https://ac.elscdn.com/S0742051X17304936/1-s2.0-S0742051X17304936-main.pdf?_tid=1dd10a4a-f85d11e7-a432-00000aab0f02\&acdnat=1515846627_818b83faf64ae9cde4b36c64a01be1a6

[14] H Bai and P.A Ertmer, Teacher educators ' beliefs and technology uses as predictors of preservice teachers ' beliefs and technolo- gy attitudes. Journal of Technology and Teacher Education, 16 (1), 93 - 112, 2008.

[15] Robots and future of welfare services (ROSE) http://roseproject.aalto.fi/

[16] S Leminen, LivingLabs as open innovation networks. Aalto University publication series. Doctoral Dissertations 132/2015. Unigrafia Oy, Helsinki, 2015. https://aaltodoc.aalto.fi

[17] S Leminen, M Westerlund and A-G Nyström, On Becoming Creative Consumers - User Roles in Living Labs Networks. International Journal of Technology Marketing, 9(1): 33-52, 2014. http://dx.doi.org/10.1504/IJTMKT.2014.058082

[18] P Reason and H Bradbury, The Sage Handbook of Action Research: Participative Inquiry and Practice. 2nd edition. Sage Publications Ltd. London, 2008.

[19] J Habermas, Knowledge and human Interests. Heinemann, London, 1972.

[20] J Pierson \& B Lievens, Configuring Living Labs for a "thick" understanding of innovation. In Proceedings of Ethnographic Praxis in Industry Conference, 114-127, 2005. http://onlinelibrary.wiley.com/doi/10.1111/j.1559-8918.2005.tb00012.x/epdf

[21] D Schuurman, L D,Marez and P Ballon, The impact of Living Lab Methodology on open innovation contributions and outcomes. Technology Innovation Management Review, 7-16, 2016. http://timreview.ca/sites/default/files/article_PDF/Schuurman_et_al_TIMReview_ January2016.pdf

[22] E Hippel, Democratizing innovation. The MITT Press, Cambridge, 2005.

[23] Laurea University of Applied Sciences, Master's Degree Programmes, 2017. https://intra.laurea.fi/en/laurea/studyprogrammes/master/Pages/default.aspx

[24] R Williams, R Slack and J Steward, Social learning in technological innovation - experimenting with information and communication technologies. Edward Elgar publishing, Cheltenhamn, 2005.

[25] M Patton, Qualitative evaluation and research methods. Sage, Beverly Hills, California, 1990.

[26] I Dey, Qualitative data analysis: a user-friendly guide for social scientists. Routledge, London, 1993. 